\title{
PENGARUH KONSENTRASI LARUTAN ASAM ASETAT DAN LAMA PERENDAMAN TERHADAP SIFAT FISIK DAN KIMIA GELATIN KULIT BABI
}

\author{
Micron Rahmad Binambuni \\ Meity Sompie \\ Indyah Wahyuni
}

\begin{abstract}
The objective of the study was to examine the extent to which the effect of different concentrations of acetic acid and the duration of immersion in acetic acid (CH3COOH) solution to the physicochemical gelatin of pigskin. This research has been carried out from September to December of 2017 at Animal Product Technology Laboratory of Faculty of Animal Husbandry of Sam Ratulangi University of Manado and the analysis was done at Food Engineering Laboratory, Faculty of Agricultural Technology Universitas Gadjah Mada Yogyakarta. This study used a $3 \times 3$ factorial pattern design with concentration treatment and long immersion in acetic acid (CH3COOH) solution, each treatment was repeated three times (Steel and Torrie, 2001). The results showed that the pigskin gelatin produced from $3 \%$ acetic acid solution and immersion time 24 hours had the best physicochemical properties.
\end{abstract}

Keywords: gelatin, pigskin and acetic acid solution

\begin{abstract}
ABSTRAK
Tujuan penelitian adalah untuk mengkaji sampai sejauh mana pengaruh konsentrasi asam asetat yang berbeda dan lama perendaman dalam larutan asam asetat $\left(\mathrm{CH}_{3} \mathrm{COOH}\right)$ terhadap fisikokimia gelatin kulit babi. Penelitian ini telah di laksanakan pada bulan September sampai Desember Tahun 2017 di Laboratorium Teknologi Hasil Ternak Fakultas Peternakan Universitas Sam Ratulangi Manado dan analisa dilakukan di Laboratorium Rekayasa Pangan, Fakultas Teknologi Pertanian Universitas Gadjah Mada Yogyakarta. Penelitian ini menggunakan Rancangan pola Faktorial 3x3 dengan perlakuan konsentrasi dan lama perendaman dalam larutan asam asetat $\left(\mathrm{CH}_{3} \mathrm{COOH}\right)$, masing-masing perlakuan di ulang sebanyak tiga kali (Steel dan Torrie, 2001). Hasil penelitian menunjukkan bahwa gelatin yang diproduksi dari kulit babi dengan konsentrasi asam asetat 3\% dengan lama perendaman dalam larutan asam asetat selama 24 jam memiliki sifat fisik dan kimia yang baik.
\end{abstract}

Kata kunci : gelatin, kulit babi dan larutan asam asetat 


\section{PENDAHULUAN}

\section{Latar Belakang}

Populasi dan pemotongan ternak babi di Sulawesi Utara cukup berlimpah karena menurut data dari Dinas Pertanian dan Peternakan Daerah Provinsi Sulawesi Utara jumlah populasi ternak Babi di Sulawesi Utara mengalami peningkatan setiap tahun. Pada tahun 2012 populasi ternak babi sebanyak 399.124, tahun 2013 sebanyak 401.991, tahun 2014 sebanyak 404.968, tahun 2015 sebanyak 408.270, tahun 2016 sebanyak 427.450. Data tersebut menunjukan bahwa potensi pemenfaatan kulit babi sebagai bahan baku pembuatan gelatin cukup menjanjikan, dimana saat ini kulit babi hanya di manfaatkan sebagai kerupuk kulit.

Gelatin adalah suatu produk yang berbentuk hidrokoloid yang berasal dari hasil hidrolisis protein kolagen hewan atau ternak, bersifat hidrofilik yang banyak terdapat pada kulit, tulang dan jaringan hewan (Said, 2014). Gelatin merupakan produk multiguna dan banyak di manfaatkan dalam industri makanan, farmasi, obat-obatan dan lain lain (Triatmojo, 2012).

Kebutuhan gelatin di dalam negeri setiap tahun meningkat, namun industri yang secara khusus memproduksi gelatin belum tersedia sehingga pemerintah masih mengimpor gelatin karena menurut data dari Biro Pusat Statistik (2018) jumlah impor gelatin mengalami peningkatan setiap tahun. Pada tahun 2013 impor gelatin sebanyak 3.149.776, tahun 2014 sebanyak 3.567.824, tahun 2015 sebanyak 3.771.040, tahun 2016 sebanyak 3.872.104, tahun 2017 sebanyak 3.990.152. Gelatin merupakan senyawa turunan yang dihasilkan dari serabut kolagen jaringan penghubung yang dihidrolisis dengan asam atau basa. Pada prinsipnya, gelatin dapat dibuat dari bahan yang kaya akan kolagen seperti kulit dan tulang baik dari babi maupun sapi atau hewan lainnya. Didalam kehidupan sehari-hari gelatin telah dimaanfaatkan sebagai bahan makanan (misalnya sebagai agen pembentuk gel, pengental, pengemulsi, pembentuk busa dan edible coating), produk farmasi (misalnya kapsul lunak dan keras), di bidang kedokteran (misalnya sebagai penutup luka) dan dalam banyak aplikasi pada non-pangan (misalnya fotografi). Diperkirakan sekitar 59\% gelatin yang telah dibuat di seluruh dunia digunakan untuk memproduksi makanan, $31 \%$ diaplikasikan pada produk farmasi, $2 \%$ dimanfaatkan untuk industri fotografi, dan sekitar $8 \%$ diaplikasikan dalam bidang lain. Hal ini disebabkan oleh keunikan dan sifat fungsionalnya yang luas untuk aplikasi dalam berbagai industri dan juga untuk meningkatkan kandungan protein pada bahan pangan. Sebagian besar masyarakat Indonesia tidak faham akan produk gelatin dan manfaat gelatin. Selama ini gelatin yang beredar di Indonesia sudah berbentuk kapsul atau sudah teraplikasi dalam makanan,hal ini dikarenakan Indonesia masih mengimpor gelatin dari Amerika dan Eropa sehingga Indonesia mengalami ketergantungan kesedian gelatin dari tahun ke tahun.Untuk keperluan industri dalam negeri, Indonesia tiap tahunnya mengimpor gelatin dalam jumlah yang cukup banyak.

Ketergantungan akan gelatin impor harus dicarikan solusi alternatif antara lain dengan memanfaatkan bahan baku lokal sebagai bahan baku gelatin. Potensi kulit Babi sebagai sumber gelatin dapat dilihat dari semakin meningkatnya jumlah populasi ternak tersebut di Provinsi Sulawesi Utara.

Pengunaan larutan asam asetat dalam pembuatan gelatin telah digunakan beberapa peneliti antara lain, gelatin dari bahan baku kulit kaki itik (Yusnaini, 2003), gelatin dari kulit babi (Sompie et al., 2012), gelatin kulit kambing (Said etal., 2011), dari kulit ikan tuna (Agustin dan Sompie, 2015), dari kulit kaki ayam (Puspawati et al., 2012), dengan lama perendaman $\mathrm{CH}_{3} \mathrm{COOH} 0,5-2 \%$, gelatin kulit kaki ayam dengan konsentrasi $3 \%$ ( Pantow et al., 2015).

Perendaman dalam larutan asam asetat dilakukan untuk membengkakan kulit lebih cepat, sehingga pada saat ekstraksi stuktur kolagen lebih mudah terurai. Kolagen yang dihidrolisis oleh larutan asam lebih banyak dari pada larutanbasa dengan mengunakan waktu yang sama, karena itu perendaman dalam 
larutan basa membutuhkan waktu yang lebih lama untuk menghidrolisis kolagen (Ward dan Courts 1977). Penggunaan asam asetat dengan konsentrasi yang berbeda dan lama perendaman yang berbeda pada pembuatan gelatin kulit babi belum banyak diteliti, oleh karena itu akan dilakukan penelitian mengenai potensi kulit babi sebagai bahan dasar pembuatan gelatin dengan perlakuan perbedaan konsentrasi dan lama perendaman dalam larutan asam asetat $\left(\mathrm{CH}_{3} \mathrm{COOH}\right)$.

\section{Rumusan Masalah}

Berdasarkan latar belakang diatas maka permasalahanya adalah apakah konsentrasi asam asetat yang berbeda dan lama perendaman larutan asam asetat $\left(\mathrm{CH}_{3} \mathrm{COOH}\right)$ memberikam pengaruh terhadap sifat fisik dan kimia gelatin.

\section{Tujuan Penelitian}

Tujuan penelitian adalah untuk mengkaji sampai sejauh mana pengaruh konsentrasi asam asetat yang berbeda dan lama perendaman dalam larutan asam asetat $\left(\mathrm{CH}_{3} \mathrm{COOH}\right)$ terhadap sifat fisik dan kimia gelatin kulit babi.

\section{Hipotesis \\ $\mathrm{H}_{0} \quad$ Perbedaan konsentrasi asam asetat $\left(\mathrm{CH}_{3} \mathrm{COOH}\right)$ dan lama perendaman gelatin memberikan pengaruh tidak nyata terhadap kekuatan gel,viskositas, rendemen, kadar air, nilai $\mathrm{pH}$.}

$\mathrm{H}_{1} \quad$ Perbedaan konsentrasi asam asetat $\left(\mathrm{CH}_{3} \mathrm{COOH}\right)$ dan lama perendaman pada pembuatan gelatin memberikan pengaruh yang nyata terhadap kekuatan gel, viskositas, rendemen, kadar air dan nilai $\mathrm{pH}$.

\section{Manfaat Penelitian}

Manfaat penelitian adalah sebagai sumber informasi ilmiah bagi masyarakat tentang potensi pengembangan gelatin dan mendayagunakan hasil ikutan pemotongan ternak babi sehingga mempunyai nilai tambah yang lebih baik dan sebagai sumber informasi ilmiah dalam pengembangan Teknologi Hasil Ternak.

\section{METODOLOGI PENELITIAN}

\section{Waktu dan Tempat Penelitian}

Penelitian telah di laksanakan pada bulan September sampai Desember Tahun 2017 di Laboratorium Teknologi Hasil Ternak Fakultas Peternakan Universitas Sam Ratulangi Manado dan analisa dilakukan di Laboratorium Rekayasa Pangan, Fakultas Teknologi Pertanian Universitas Gadjah Mada Yogyakarta.

\section{Materi Penelitian}

Bahan utama yang digunakan dalam penelitian ini adalah kulit Babi yang telah diambil di pasar tradisional, larutan asam asetat $\left(\mathrm{CH}_{3} \mathrm{COOH}\right)$ dan aquades. Peralatan yang di gunakan adalah gelas ukur, labu takar, gunting, pisau, wadah plastik, saringan, waterbath, toples, untuk perendaman, corong, pengerus, viscometer Brookville, labu kjeldahl, erlemeyer, $\mathrm{pH}$ meter, cetakan (wadah pengering), oven, desikator, pipet, dan lemari pendingin.

\section{Metode Penelitian}

Penelitian ini menggunakan Rancangan pola Faktorial 3x3 dengan perlakuan konsentrasi dan lama perendaman dalam larutan asam asetat $\left(\mathrm{CH}_{3} \mathrm{COOH}\right)$, masing-masing perlakuan di ulang sebanyak tiga kali (Steel dan Torrie, 2001).

Perlakuan adalah konsentrasi yang berbeda dan lama perendaman dalam larutan asam asetat $(\mathrm{P})$ :

Faktor A, konsentrasi larutan asam asetat

$\mathrm{A}_{1}=3 \%$

$\mathrm{A}_{2}=5 \%$

$\mathrm{A}_{3}=7 \%$

Faktor B, lama perendaman dalam larutan asam asetat

$$
\begin{aligned}
& \mathrm{B}_{1}=24 \mathrm{Jam} \\
& \mathrm{B}_{2}=48 \mathrm{Jam} \\
& \mathrm{B}_{3}=72 \mathrm{Jam}
\end{aligned}
$$

\section{Pengukuran Variabel}

Variabel yang akan di amati dalam penelitian ini adalah :

1. Kekuatan Gel

2. Viskositas

3. Rendeman

4. Kadar Air

5. Nilai $\mathrm{pH}$ 


\section{Proses Pembuatan Gelatin.}

Menurut Said et al (2011) dan Sompie et al (2012) proses pembuatan gelatin secara asam adalah kulit ternak setelah lepas dari tulang dicuci, direndam dalam air hangat selama 30 menit untuk menghilangkan lemak. Selanjutnya dicuci, dipotong ukuran 1-2 $\mathrm{cm}^{2}$. Selanjutnya sampel kulit yang dipotong direndam dalam larutan asam asetat $\left(\mathrm{CH}_{3} \mathrm{COOH}\right)$ selama $24 \mathrm{jam}$. Perbandingan kulit larutan perendaman 1:3. Setelah direndam dicuci dengan air mengalir berulang kali sampai $\mathrm{pH}$ netral. Selanjutnya kulit hasil rendaman diekstraksi dalam water bath dengan suhu $55^{\circ} \mathrm{C}$ selama 5 jam. Proses selanjutnya penyaringan larutan gelatin menggunakan kertas saring. Larutan gelatin yang diperoleh dituang kedalam wadah berukuran 30,5 $\mathrm{cm} \times 30,5 \mathrm{~cm}$, kemudian dikeringkan dalam oven dengan suhu $60^{\circ} \mathrm{C}$ selama 24-72 jam. Lembaran gelatin yang diperoleh kemudian dihaluskan dengan menggunakan blender dan disimpan dalam desikator. Untuk lebih jelasnya dapat dilihat pada diagram alir dibawah ini (Gambar 1).

\section{Kekuatan Gel}

\section{Prosedur Analisis:}

Uji kekuatan gel dilakukan menurut metode Muyonga et al. (2004), dengan cara bubuk gelatin dilarutkan dalam aquades pada suhu $60^{\circ} \mathrm{C}$ dengan konsentrasi larutan $6,67 \% \mathrm{w} / \mathrm{v}(6,67 \mathrm{w} / \mathrm{v} \mathrm{g}$ sampel $100 \mathrm{ml}$ aquades). Larutan yang terbentuk dimasukan dalam wadah yang diameternya $5 \mathrm{~cm}$ dengan tinggi $6 \mathrm{~cm}$ kemudian di simpan pada suhu $5^{\circ} \mathrm{C}$ selama 16-18 jam. Sampel yang telah siap untuk diuji diletakan dalam plunger $(\mathrm{d}=13 \mathrm{~mm})$ pada suhu $10^{\circ} \mathrm{C}$. Hasil pembacaan gaya maksimum yang diberikan plunger penetrasi dalam gel 10 $\mathrm{mm} /$ menit sedalam $4 \mathrm{~mm}$. Perhitungan nilai kekuatan gel dilakukan dalam satuan $\mathrm{g}$ bloom. Rumus yang digunakan mengkonversikan F. max dalam satuan $\mathrm{N} / \mathrm{cm}^{2}$ (dyne/ $\mathrm{cm}^{2}$ ) ke g Bloom adalah dengan persamaan sebagai berikut: Kekuatan gel $(\mathrm{g}$ Bloom $)=20+2,86.10^{-3} \mathrm{D}$

$\mathrm{D}\left(\right.$ Dyne $\left./ \mathrm{cm}^{2}\right)=\frac{F}{G} \times 980$

$\mathrm{F}=$ Tinggi grafik sebelum patah

$\mathrm{G}=$ Konstanta $(0,07)$

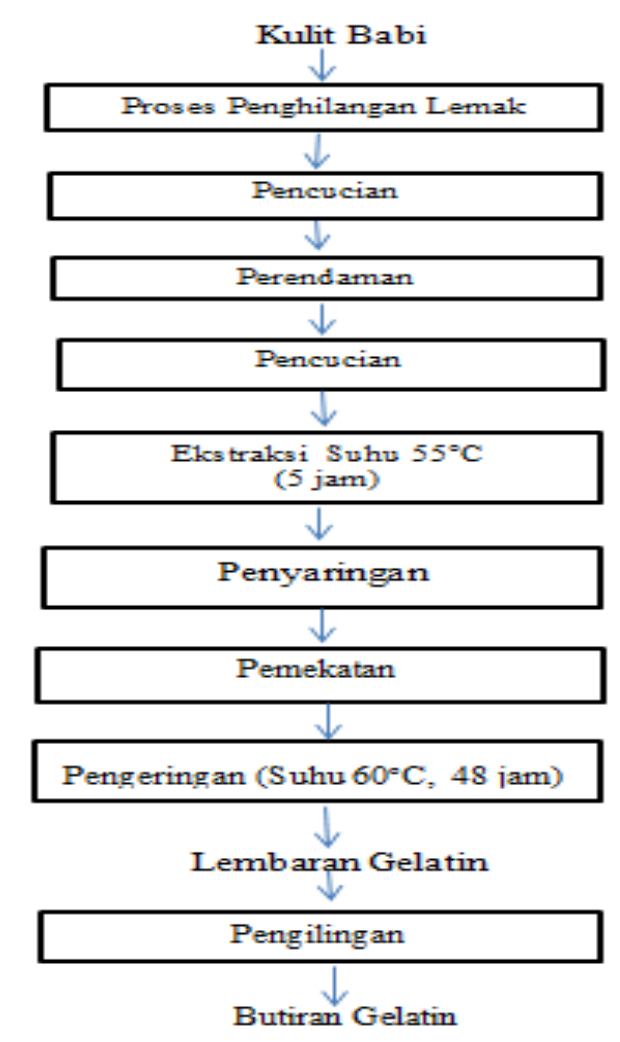

Gambar 1. Diagram Alir Proses Pembuatan Gelatin (Sumber : Said et al 2011)

2. Viskositas

Uji viskositas dilakukan menurut metode Anersen et al. (2005) dengan cara bubuk gelatin dilarutkan dalam aquades pada suhu $60^{\circ} \mathrm{C}$ dengan konsentrasi larutan 6,67\% w/v (6,67 g sampel $100 \mathrm{ml}$ aquades). Larutan gelatin di tuang ke alat sejenis mangkuk yang sebelumnya telah diberi air pada bagian luar mangkuk untuk mengontrol pergerakan temperatur sampel. Pengujian dlakukan pada suhu kamar $28^{\circ} \mathrm{C}$. nilai viskositas diukur dengan stromer Viscosimeter Behlin CSR-10. Pencatatan waktu yang ditempuh spindle dalam 1 kali putaran dilakukan sebanyak 3 kali untuk selanjutnya dirata-rata. Hasil rata-rata (detik) kemudian dikonversi ke dalam persamaan:

Viskositas $(\mathrm{cP})=\frac{\text { A x waktu putar rata-rata(detik) }}{B}$

Keterangan :

$\mathrm{A}=$ nilai viskositas pada suhu $28^{\circ} \mathrm{C}$

$\mathrm{B}=$ waktu putar rata-rata hasil kalibrasi (detik) 
3. Rendemen

Rendemen diperoleh dari perbandingan berat kering gelatin yang dihasilkan dengan berat kulit yang di ekstraksi sompie et al., (2012).

$$
\text { Rendemen }(\%)=\frac{\text { Berat Gelatin }}{\text { Berat Kulit }} \times 100
$$

4. Kadar Air

Sampel seberat 3 gram dimasukan ke dalam cawan logam yang telah diketahuhi beratnya. Kemudian cawan berisi sampel dimasukan kedalam oven dengan suhu $105^{\circ} \mathrm{C}$ selama 4-6 jam hingga berat cawan dan sampel konstan. Setelah itu dimasukan ke dalam desikator dan ditimbang beratnya, kemudian dihitung persentas kadar air sampel (AOAC, 1995).

Kadar air dihutung sebagai berikut:

kadar air $(\%)=\frac{\text { bobot sampel awal }- \text { bobot sampel akhir }}{\text { bobot sampel awal }} \times 100$

5. Nilai $\mathrm{pH}$

Nilai $\mathrm{pH}$ diuji menggunakan $\mathrm{pH}-$ meter. Sampel gelatin dilarutkan dengan menggunakan aquades dengan perbandingan 1: 5 dan diaduk sampai homogen. Elektro $\mathrm{pH}$ meter dikalibrasi menggunakan larutan buffer sampai nilai $\mathrm{pH}$ mencapai 6,8 sampai 7. Kemudian Elektro pH meter dicelupkan sampel sampai muncul angka nilai $\mathrm{pH}$ pada layar. Setelah selesai dicelupkan kedalam buffer atau sampel, sensor dicuci menggunakan aquades dan dikeringkan menggunakan tisu agar pengukuran akurat.

\section{HASIL DAN PEMBAHASAN}

\section{Kekuatan Gel}

Nilai kekuatan gel gelatin kulit kaki babi dengan perlakuan konsentrasi dan lama perendaman dalam larutan asam asetat ditampilkan pada Tabel 1.

Tabel 1. Rataan kekuatan gel (g / Bloom) gelatin kulit babi

\begin{tabular}{|c|c|c|c|c|}
\hline \multirow{2}{*}{$\begin{array}{c}\text { Konsentrasi asan } \\
\text { asetat (\%) }\end{array}$} & \multicolumn{3}{|c|}{ Lama Perendaman (jam) } & \multirow[t]{2}{*}{ Rataan } \\
\hline & 24 & 48 & 72 & \\
\hline 3 & $73,05 \pm 1,99$ & $74,11 \pm 0,90$ & $75,13 \pm 0,35$ & $74,09 \pm 1,99^{\mathrm{a}}$ \\
\hline 5 & $69,63 \pm 1,99$ & $70,36 \pm 0,07$ & $70,61 \pm 0,14$ & $70,20 \pm 0,79^{\mathrm{b}}$ \\
\hline 7 & $67,14 \pm 0,26$ & $67,79 \pm 0,38$ & $67,92 \pm 0,20$ & $67,61 \pm 1,25^{\mathrm{c}}$ \\
\hline Rataan & $69,94 \pm 3,58$ & $70,75 \pm 3,02$ & $71,22 \pm 3,14$ & \\
\hline
\end{tabular}

menunjukkan perbedaan yang nyata $(\mathrm{P}<0,05) ; \mathrm{Sd}=$ Standar deviasi .
Hasil analisis sidik ragam menunjukkan bahwa interaksi antara kedua faktor, konsentrasi asam setat dan lama perendaman memberikan pengaruh yang berbeda tidak nyata $(\mathrm{P}>0,05)$ terhadap kekuatan gel gelatin kulit babi. Untuk masing-masing faktor, perlakuan konsentrasi asam asetat memberikan pengaruh yang sangat nyata $(\mathrm{P}<0,01)$ sedangkan perlakuan lama penyimpanan berbeda tidak nyata $(\mathrm{P}>0,05)$ terhadap kekuatan gel gelatin kulit babi.

Hasil uji Duncan untuk perlakuan konsentrasi asam asetat menunjukkan bahwa gelatin kulit babi yang diproduksi dengan menggunakan larutan asam asetat 3\% lebih tinggi dari konsentrasi $5 \%$ dan $7 \%$. Dengan kata lain kekuatan gel cenderung menurun dengan meningkatnya konsentrasi asam asetat. Hal ini sesuai dengan pernytaan Arnesen and Gildberg (2002) menyatakan bahwa kandungan hidroksiprolin yang rendah menyebabkan rendahnya kekuatan gel gelatin. Kekuatan gel berhubungan dengan kemampuan mengubah cairan menjadi padatan atau mengubah bentuk sol menjadi gel yang bersifat reversibel. Ciri khas gelatin yaitu kemampuannya untuk membentuk gel (Glicksman, 1969). Hasil penelitian ini masih termasuk dalam kisaran standar mutu gelatin tipe asam yaitu 50 - $280 \mathrm{~g}$ Bloom (Said et al 2011 dan Sompie et al., 2012).

\section{Viskositas}

Viskositas gelatin kulit kaki babi dengan perlakuan konsentrasi dan lama perendaman dalam larutan asam asetat disajikan pada Tabel 2 berikut ini

Tabel 2. Rataan viskositas (cP) gelatin kulit babi

\begin{tabular}{|c|c|c|c|c|}
\hline \multirow{2}{*}{$\begin{array}{c}\text { Konsentrasi asam } \\
\text { asetat }(\%)\end{array}$} & \multicolumn{3}{|c|}{ Lama Perendaman (jam) } & \multirow[t]{2}{*}{ Rataan } \\
\hline & 24 & 48 & 72 & \\
\hline 3 & $8,53 \pm 015$ & $8,26 \pm 0,05$ & $8,33 \pm 0,16$ & $8,37 \pm 0,16^{\mathrm{a}}$ \\
\hline 5 & $8,30 \pm 0,10$ & $8,25 \pm 0,05$ & $8,35 \pm 0,06$ & $8,30 \pm 0,07^{\mathrm{a}}$ \\
\hline 7 & $7,53 \pm 0,20$ & $7,79 \pm 0,30$ & $8,08 \pm 0,02$ & $7,80 \pm 0,26^{\mathrm{b}}$ \\
\hline Rataan & $8,12 \pm 0,45$ & $8,10 \pm 0,24$ & $8,26 \pm 0,16$ & \\
\hline
\end{tabular}

Keterangan: notasi huruf yang berbeda pada baris dan kolom yang sama menunjukkan perbedaan yang nyata $(\mathrm{P}<0,05) ; \mathrm{Sd}=$ Standar deviasi.

Hasil analisis sidik ragam menunjukkan bahwa interaksi antara konsentrasi asam asetat dan lama perendaman memberikan pengaruh yang berbeda tidak nyata $(\mathrm{P}>0,05)$ terhadap nilai viskositas gelatin kulit babi. 
Untuk masing-masing faktor, perlakuan konsentrasi asam asetat memberikan pengaruh yang nyata $(\mathrm{P}<0,05)$ sedangkan perlakuan lama penyimpanan berbeda tidak nyata $(\mathrm{P}>0,05)$ terhadap viskositas gel gelatin kulit babi.

Hasil uji Duncan untuk faktor konsentrasi asam asetat menunjukkan bahwa gelatin kullit babi yang diproduksi dengan menggunakan asam asetat $3 \%$ dan $5 \%$ memiliki nilai viskositas yang sama dan nyata lebih tinggi dari nilai viskositas gelatin yang menggunakan konsentrasi asam asetat $7 \%$. Dengan kata lain semakin tinggi konsentrasi asam asetat, semakin menurun nilai viskositas gelatin kulit babi. Penurunan viskositas gelatin ini di sebabkan karena asam asetat dapat memecah ikatan peptida asam amino menjadi rantai molekul yang pendek sehingga viskositasnya menurun (Leiner, 2002 dalam Said et al, 2011). Rataan nilai viskositas yang diperoleh pada penelitian ini berkisar antara 7,53 - 8,53 cP. Nilai viskositas ini masih pada kisaran standar mutu gelatin yang baik (Rares et al. 2016).

\section{Rendemen}

Nilai rendemen gelatin kulit babi dengan perlakuan konsentrasi dan lama perendaman dalam larutan asam asetat ditampilkankan pada Tabel 3 berikut ini

\begin{tabular}{|c|c|c|c|c|}
\hline \multirow{2}{*}{$\begin{array}{c}\text { Konsentrasi } \\
\text { asam asetat }(\%)\end{array}$} & \multicolumn{3}{|c|}{ Lama Perendaman (jam) } & \multirow[t]{2}{*}{ Rataan } \\
\hline & 24 & 48 & 72 & \\
\hline 3 & $12,28 \pm 0,49$ & $12,41 \pm 0,29$ & $12,57 \pm 0,25$ & $12,42 \pm 0,23^{\mathrm{a}}$ \\
\hline 5 & $13,24 \pm 0,32$ & $13,35 \pm 0,32$ & $13,42 \pm 0,23$ & $13,34 \pm 0,26^{\mathrm{b}}$ \\
\hline 7 & $13,58 \pm 0,21$ & $13,68 \pm 0,42$ & $13,85 \pm 0,16$ & $13,70 \pm 0,27^{\mathrm{c}}$ \\
\hline Rataan & $13,16 \pm 0,72$ & $13,11 \pm 0,63$ & $13,19 \pm 0,50$ & \\
\hline
\end{tabular}

Hasil analisis sidik ragam menunjukkan bahwa interaksi antara perlakuan konsentrasi asam asetat dan lama perendaman memberikan pengaruh yang berbeda tidak nyata $(\mathrm{P}>0,05)$ terhadap rendemen gelatin kulit babi, tetapi perlakuan konsentrasi asam asetat memberikan pengaruh yang nyata $(\mathrm{P}<0,05)$.
Hasil uji Duncan untuk faktor konsentrasi asam asetat menunjukkan bahwa gelatin kullit babi yang diproduksi dengan menggunakan konsentrasi asam asetat $7 \%$ memiliki nilai rendemen yang lebih tinggi dari gelatin kulit babi yang menggunakan konsentrasi asam asetat $3 \%$ dan $5 \%$. Dengan kata lain nilai rendemen gelatin kulit babi memiliki kecenderungan naik dengan peningkatan konsentrasi asam asetat. Hal ini disebabkan karena semakin tinggi konsentrasi asam asetat maka struktur kolagen akan lebih terbuka dan semakin banyak kolagen yang terhidrolisis sehingga gelatin yang terekstraksi akan semakin banyak. Menurut Chamidah dan Elita (2002), larutan asam berfungsi untuk menghidrolisis kolagen sehingga mempermudah kelarutannya pada saat ekstraksi gelatin, karena struktur kolagen terbuka akibat beberapa ikatan dalam molekul proteinnya terlepas. Hal ini sejalan dengan hasil penelitian Ulfah (2011) bahwa semakin tinggi konsentrasi asam asetat semakin banyak rendemen gelatin yang dihasilkan. Nilai rendemen gelatin kulit babi pada penelitian ini berada pada kisaran $12,28-13,85 \%$ dan sesuai dengan kisaran standar industri gelatin (GMIA, 2012).

\section{Kadar Air}

Kadar air merupakan parameter penting dari suatu produk pangan, khususnya produkproduk yang bentuknya kering. Rataan kadar air dengan perlakuan konsentrasi dan lama perendaman dalam larutan asam asetat disajikan pada Tabel 4 berikut ini.

\begin{tabular}{|c|c|c|c|c|}
\hline \multirow{2}{*}{$\begin{array}{l}\text { Konsentrasi } \\
\text { asam asetat }(\%)\end{array}$} & \multicolumn{3}{|c|}{ Lama Perendaman (jam) } & \multirow[t]{2}{*}{ Rataan } \\
\hline & 24 & 48 & 72 & \\
\hline 3 & $7,57 \pm 0,03$ & $7,51 \pm 0,01$ & $7,52 \pm 0,92$ & $7,53 \pm 0,34^{\mathrm{a}}$ \\
\hline 5 & $6,89 \pm 0,11$ & $6,72 \pm 0,02$ & $6,79 \pm 0,03$ & $6,80 \pm 0,09^{\mathrm{b}}$ \\
\hline 7 & $6,12 \pm 0,02$ & $6,12 \pm 0,02$ & $6,09 \pm 0,02$ & $6,11 \pm 0,50^{\mathrm{c}}$ \\
\hline Rataan & $6,86 \pm 0,62^{\mathrm{c}}$ & $6,78 \pm 0,60^{\mathrm{d}}$ & $6,80 \pm 0,62^{\mathrm{d}}$ & \\
\hline
\end{tabular}

Berdasarkan hasil analisis sidik ragam menunjukkan bahwa interaksi antara faktor konsentrasi dan lama perendaman dalam larutan asam asetat berpengaruh tidak nyata $(\mathrm{P}>0,05)$ terhadap kadar air gelatin kulit babi. Untuk masingmasing faktor perlakuan konsentrasi asam asetat memberikan pengaruh yang nyata $(\mathrm{P}<0,05)$ begitu juga dengan perlakuan lama penyimpanan berpengaruh nyata $(\mathrm{P}<0,05)$ terhadap kadar air gelatin kulit babi. 
Hasil uji Duncan untuk faktor konsentrasi asam asetat menunjukkan bahwa gelatin kulit babi yang diproduksi menggunakan larutan asam asetat konsentrasi 3\% memiliki kadar air lebih tinggi dibandingkan dengan konsentrasi asam asetat $5 \%$ dan $7 \%$, artinya semakin meningkat konsentrasi asam asetat nilai kadar air gelatin semakin menurun. Penurunan kadar air gelatin kulit babi ini dikarenakan perendaman dalam larutan asam asetat akan semakin banyak asam yang terdifusi dalam jaringan kulit babi menyebabkan struktur kolagen semakin terbuka dan ikatannya lemah, dan menghasilkan struktur gelatin dengan ikatan lemah.

Hasil uji Duncan untuk faktor lama perendaman menunjukkan bahwa gelatin yang menggunakan lama perendaman 48 dan 72 jam memiliki nilai kadar air yang sama namun lebih rendah dari lama perendaman 24 jam. Penurunan kadar air gelatin ini disebabkan oleh struktur kolagen yang semakin terbuka (Astawan dan Aviana, 2003), dengan ikatan yang lemah akibatnya menghasilkan gelatin dengan struktur yang lemah, sehingga daya ikat air pada gelatin juga kurang kuat. Nilai kadar air gelatin yang diperoleh pada penelitian ini berada pada kisaran $6 \%$ - 10\%, nilai ini masih memenuhi standar mutu gelatin yang ditetapkan SNI (1995) yaitu maksimal $16 \%$ (Sompie et al. 2012).

\section{Nilai (pH)}

Nilai $\mathrm{pH}$ merupakan salah satu sifat kimia gelatin yang penting. Rataan nilai $\mathrm{pH}$ gelatin kulit babi disajikan pada Tabel 5 berikut ini.

Tabel 5. Rataan pH gelatin kulit babi

\begin{tabular}{|c|c|c|c|c|}
\hline \multirow{2}{*}{$\begin{array}{c}\text { Konsentrasi } \\
\text { asam asetat }(\%) \\
\end{array}$} & \multicolumn{3}{|c|}{ Lama Perendaman (jam) } & \multirow[t]{2}{*}{ Rataan } \\
\hline & 24 & 48 & 72 & \\
\hline 3 & $5,34 \pm 0,11$ & $5,33 \pm 0,11$ & $5,30 \pm 0,12$ & $5,32 \pm 0,19$ \\
\hline 5 & $5,22 \pm 0,11$ & $5,20 \pm 0,05$ & $5,21 \pm 0,05$ & $5,21 \pm 0,11$ \\
\hline 7 & $5,22 \pm 0,12$ & $5,21 \pm 0,12$ & $5,22 \pm 0,16$ & $5,21 \pm 0,50$ \\
\hline Rataan & $5,26 \pm 0,06$ & $5,25 \pm 0,05$ & $5,25 \pm 0,04$ & \\
\hline
\end{tabular}

Hasil analisis sidik ragam menunjukkan bahwa interaksi antara konsentrasi asam asetat dan lama perendaman dalam larutan asam asetat memberikan pengaruh yang berbeda nyata $(\mathrm{P}<0,05)$ terhadap nilai $\mathrm{pH}$ gelatin yang dihasilkan. Hasil uji Duncan untuk faktor konsentrasi asam asetat menunjukkan bahwa nilai $\mathrm{pH}$ gelatin yang menggunakan konsentrasi $5 \%$ sama dengan konsentrasi 7\%, lebih rendah dari gelatin yang menggunakan konsentrasi asam asetat $3 \%$. Artinya semakin meningkat konsentrasi asam asetat, nilai $\mathrm{pH}$ semakin rendah. Rendahnya $\mathrm{pH}$ disebabkan karena masih terdapat larutan asam asetat yang terperangkap pada saat proses swelling sehingga tidak hilang pada waktu pencucian kulit (Taufik, 2011). Selanjutnya hasil uji Duncan untuk faktor lama perendaman menunjukkan bahwa nilai $\mathrm{pH}$ gelatin yang menggunakan lama perendaman 24, 48 dan 72 jam memiliki nilai $\mathrm{pH}$ yang sama. Nilai $\mathrm{pH}$ yang dihasilkan dalam penelitian ini berkisar antara 5,20 - 5,34 tidak jauh berbeda dengan nilai $\mathrm{pH}$ gelatin komersil yakni 5,77 dan masih termasuk dalam standar gelatin industri (Taufik, 2011 dan Sompie et al., 2012).

\section{KESIMPULAN}

\section{Kesimpulan}

Kesimpulan dari penelitian ini adalah gelatin yang diproduksi dari kulit babi dengan konsentrasi asam asetat 3\% dengan lama perendaman dalam larutan asam asetat selama 24 jam memiliki sifat fisik dan kimia yang baik.

\section{DAFTAR PUSTAKA}

Agustin A. T dan M Sompie. 2015. Kajian Gelatin Kulit Ikan Tuna (Thunnus albacore Yang Diproses Menggunakan Asam Asetat. Prossiding Seminar Nasional Masyarakat Biodiversitas Indonesia, 1 (5) (1186 1189). ISSN 2407-8050.

Anersen, J. A and A. Gilberg. 2005. Ekstraction And Characterization Of Gelatin From Atlantic Salmon (Salmosar) Skin. Bioresource Technology.

Astawan, M., Hariyadi, P., Mulyani, A. 2002. Analisis Sifat Reologi Gelatin dari Kulit Ikan Cucut . Jurnal Teknologi dan Industri Pangan. 
Pantow, I.M., M. Sompie., A.Dp. Mirah., L.Ch.M. Karisoh, 2015. Pengaruh Konsentrasi Asam Asetat Terhadap Karakteristik Kulit Kaki Ayam. Zootek. Vol 36 (1)

Puspawati, N. M dan I. N. Smpen., I. N. Sumentra Miweda. 2012. Isolasi Gelatin Dari Kulit Kaki Ayam Broiler Dan Karakterisasi Gugus Fungsinya Dengan Spektrofotometri FTIR. Fakultas peternakan. Universitas Udayana. Denpasar. ISSN 1970-9850.

Rares, R., M. Sompie, A. Mirah., J. Kalele., 2016. Pengaruh Lama Perendaman Dalam Larutan Asam Asetat $\left(\mathrm{CH}_{3} \mathrm{COOH}\right)$ terhadap Karakteristik Fisik dan Kimia Gelatin Ceker Ayam. J. Zootek 37(2) : 268-275.

Said, M. I., 2014. By Product Ternak, Teknologi Dan Aplikasinya, IPB Press Bogor.

Said, M. I., S. Triatmojo., Y. Erwanto, A, Fudholi 2011. Karakteristik Gelatin Kulit Kambing Yang Di Produksi Melalui Proses Asam Basa, J, Agritech, 31 (3) $: 190$ - 200.

Sompie, M., S. C. Rimbing., S.E. Surtijono, F. Ratulangi,2014. Pengaruh Konsentrasi Asam Asetat Dan Suhu Ekstraksi Terhadap Karakteristik Gelatin Kulit Babi. Prossiding Seminar Nasional Himpunan Kimia Indonesia, 1 (1) :65 69.

Sompie, M., S. E. Surtijono,. J.W. Pontoh., N. Lontaan., 2015. Effect of Acetic Acid Concertration and Temperature Extraction On Physical and Chemical Properties of Pigskin Gelatin. Procedia Food Science, 3 (1): 383-388.
Sompie, M., S. Triatmojo,. A. Pertiwiningrum, Y. Pratono. 2012. Pengaruh umur potong dan Konsentrasi Larutan Asam Asetat terhadap sifat Fisik da Kimia Gelatin kulit Babi. Sains Peternakan 10 (1) : $15-22$.

Sompie, M., S. Triatmojo,. A. Pertiwiningrum, Y. Pratono. 2012. The Effect Of Animal Age And Acetic Concertration On Pigskin Gelatin Charateristic, J. Indonesia Tropical Animal Agriculture.

Steel, R. G. D. and J. H. Torrie. 1991. Principles and Procedures of Statistics. McGraw-Hill Book Co. Inc. New York

Taufik, M. 2011. Plastizer Terhadap Karakteristik Edible Film Serts Aplikasi Minyak Cengkeh Sebagai Anti Bakteri Dalam Edible Film Berbahan Dasar Gelatin Kulit Kaki Ayam Broiler. Seminar Hasil Penelitian. PPS Peternakan UGM Yogyakarta.

Triatmojo.S., A. Pertiwiningrum., Y, Erwanto, N. Kurniawan, 2012. Bahan Ajar Hasil Teknologi Ikutan Ternak. Laboratorium Hasil Ikutan Dan Lingkungan. Teknologi Hasil Ternak. Fakultas Peternakan Universitas Gaja Mada. Yogyakarta.

Ulfah, M. 2011. Pengaruh Konsentrasi Larutan Asam Asetat Dan Lama Waktu Perendaman Terhadap Sifat - Sifat Gelatin Ceker Ayam. J. Agritech. 31 (3) : 161 167.

Ward A G, and Courts A. 1977. The Science and Technology of Gelatin. Academics Press, New York

Yusnaini, 2003. Kuantitas Dan Kualitas Gelatin Kulit Kaki Itik Melelui Proses Asam Dan Basa Dengan Lama Perendaman Yang Berbeda.Tesis. Program Pasca Sarjana Universitas Hassanudin Makasar. Makasar 